\title{
Patch Formulation of Celery Leaves Extract (Apium Graveolens L.) As Mosquito Repellent
}

\author{
$1^{\text {st }}$ Ratnaningsih Dewi Astuti \\ Department of Pharmacy, \\ Politeknik Kesehatan Kemenkes Palembang \\ Palembang, Indonesia \\ ratnaningsih_plg@yahoo.com
}

\author{
$2^{\text {nd }}$ Siti Khotimah \\ Department of Pharmacy, \\ Politeknik Kesehatan Kemenkes Palembang \\ Palembang, Indonesia \\ khotimah649@gmail.com
}

Corresponding Author: ratnaningsih_plg@yahoo.com

\begin{abstract}
- the transdermal patch preparation which contains repellent active substances. The combination of PVA and PVP polymers can produce strong, nonbreakable, elastic, and transparent preparations. This study aims to determine the concentration of the right combination of PVA and PVP to produce a safe and stable preparation. The repellent patch is made using the active substance of the methanol extract of celery leaves (Apium graveolens .L) which is useful as a natural repellent. This study used an experimental method with the active substance of leaf methanol extract Celery (Apium graveolens .L) obtained from the maceration process is then vacuum distilled. The extract used was $15 \%$ for each formula with variations in the combination of PVA and PVP for the control formula and formula I 1: 1, formula II 1: 1,5, and formula III 1: 2 . After being formulated, the preparation will be evaluated for 28 days of storage which includes $\mathrm{pH}$ test, weight uniformity, thickness, percentage of moisture, folding resistance, and organoleptic. The evaluation results showed that all the repellent patch formulas met the requirements for 28 days of storage. All formulas have a $\mathrm{pH}$ that tends to increase with a $\mathrm{pH}$ range of $4.52-6.95$, has an increase in weight with a range of $0.1443-0.1553$, has a thickness that tends to increase with a range of $0.21-0.30$, has an increase in the percentage of moisture with a range of $5.79 \%-\mathbf{7 . 9 4 \%}$, did not experience damage or breakage after folding $>300$ times and did not experience a change in color and odor. Leaf methanol extract celery (Apium graveolens .L) can be formulated into a stable and fulfilling repellent patch preparation with the most optimal formula is formula II with a combination of polymer concentration is $1: 1.5$.
\end{abstract}

Keywords: patch, repellent, $P V A, P V P$.

\section{INTRODUCTION}

Patch preparations are drugs that are prepared in the form of an adhesive to be placed on the skin, have different sizes and are retained on the skin for a long period of time(1)The new patch formulation currently being developed is a patch preparation containing repellent. Patch preparations can be a repellent choice because they are thin, easy to use and apply. Repellent patches work as an insect repellent so they don't land and bite humans. Insects have become a major factor in spreading disease sources through the spread of viruses and bacteria, for example, mosquitoes. The large population of Aedes aegypti sp. Mosquitoes have resulted in high cases of dengue fever in Indonesia. In 2017, cases of dengue fever in Indonesia reached 59,047 cases and South Sumatra contributed as many as 1,449 (2)The high mortality rate due to dengue fever needs to be suppressed with various efforts, both curative and preventive. One of the preventive measures that can be done is to use anti-mosquito preparations such as repellent patches. Works by spreading odors or odors of active substances that affect the smell of insects. The spread of odors can be controlled with polymeric substances.

Polymers are giant molecules formed by rearranging small molecules that are bonded by chemical bonds called polymers. Polymers have been used as slowrelease slowing agents which are useful in the spatial emanation of insecticides at desired concentrations (3)The polymer application of the patch preparation is a substance to control drug release and can be used to formulate a variety of controlled drug delivery 
systems. Polymers are divided into three categories, namely natural polymers, synthetic elastomeric polymers, and synthetic polymers. PVP (Polyvinyl pyrrolidone) and PVA (Polyvinyl alcohol) are types of synthetic polymers that can produce thin and flexible preparations because the properties of the substance are easier to adjust the shape and content (4) The combination of PVP and PVA has similar properties, namely water solubility, but the lack of PVP, in this case, is that if it is given excessively it will cause the mixture to become inhomogeneous. If you give too much PVA, the preparation will become harder because of the polar bonds that come from hydrophilic polymers so that it will strengthen the bonds between the polymer and other materials.

There are differences in polymer properties in the formation of patches, so research on patches is conducted. In research [5] PVA and PVP have the best combination in $\mathrm{NaF}$ patch preparations with a concentration of $20 \%$ with a ratio of $2: 1$ compared to other PVA and PVP ratios, namely 1: 1 and 1: 2 . Judging from the thinner, lighter dosage, has the highest folding resistance and the smallest dry percentage. This polymer combination has also been formulated into a repellent patch with a ratio of 1: 1 and the effectiveness of the extract is $15 \%$ seen from the effectiveness of the patch in reducing mosquitoes that land on the respondent's body (5) Patch preparations, especially repellent patches, are generally chemical substances. The main chemical substance that is often used is DEET (N, N-Diethylmeta-toluamide). DEET works by creating odors or by affecting the body odor of humans or animals so that they avoid mosquito bites. However, using DEET can cause skin irritation and respiratory problems(6) Therefore, for safer use, research is carried out using plants or their active substances as repellents.

Based on research(7) who tested the effectiveness of the repellent against the Aedes Aegypti sp. By comparing the methanol extract of celery leaves with a concentration of $5 \%, 10 \%$ and $15 \%$ with baygon as a positive control states that celery leaves have been proven to be mosquito repellent with a concentration of $15 \%$. Celery leaves contain essential oils, sesquiterpene alcohol (1-3\%) and fatty acids which act as natural repellents. The effectiveness of plants containing secondary metabolites, such as saponins, steroids, isoflavonoids, essential oils, alkaloids and tannins as potential mosquito larvicides and also as insecticides against mosquitoes (8)The use of celery leaf extract as the main substance can be added with vanillin to increase the duration of effectiveness, the greater the concentration of the mixture of celery leaf extract and vanillin the longer the effective repellent time of the preparation (9). Celery leaves have also been used in the community as a natural mosquito repellent which is processed to be used as a repellent.

Therefore, regarding celery leaf methanol extract as a natural insecticide for mosquitoes and cengkeh leaf repellent patch preparation, researchers have researched the formulation and evaluation of repellent patch preparations containing methanol extract of celery leaves (Apium graveolens, $\mathrm{L}$ ) with variations of PVP polymer.

\section{METHOD}

\section{A. Types of research}

This research will be conducted using experimental methods by making several formulations containing repellent patches celery leaf extract (Apium graveolens .L).

\section{B. Tools and Materials}

The tools used are Measuring cups, gram scales, gram weights, glass stirrers, analytical scales, wood tongs, water bath, watch glasses, $\mathrm{pH}$ meters, desiccators, screw micrometers, rulers, questionnaires, parchment paper. The materials used were celery leaf methanol extract (Apium graveolens .L), Polyvinyl Pyrrolidone (PVP), Polyvinyl Alcohol (PVA), Polyethylenglycol 400 (PEG400), Aquadest, Silica Gel, Ethanol.

\section{Extraction}

Celery leaves are cut into small pieces, then dried, and then blended until they become powder. Then put in a chocolate bottle (maceration bottle). The powder was soaked in methanol with a ratio of every 50 grams of celery leaf powder soaked in $500 \mathrm{ml}$ of methanol for 72 hours and stirred 4-5 times a day. Filtration is obtained from the filtering using 4 layers of gauze. Separation of methanol from the extract was carried out using a rotary vacuum evaporator at a temperature of $40 \mathrm{oC}$, until all of the methanol evaporated and a thick extract of celery leaves was obtained. 


\section{D.Patch Formulation}

Table 1. Patch Formulation

\begin{tabular}{cccccc}
\hline \multicolumn{5}{c}{ Amount Used } \\
\hline Material & $\begin{array}{c}\text { Control } \\
\text { Formul }\end{array}$ & $\begin{array}{c}\text { Formula } \\
\text { I }\end{array}$ & $\begin{array}{l}\text { Formula } \\
\text { II }\end{array}$ & $\begin{array}{c}\text { Formula } \\
\text { III }\end{array}$ & Ket \\
\hline $\begin{array}{c}\text { Celery } \\
\text { Leaf } \\
\text { Extract }\end{array}$ & - & $15 \%$ & $15 \%$ & $15 \%$ & $\begin{array}{c}\text { Active } \\
\text { substance }\end{array}$ \\
\hline PVA & $7 \%$ & $7 \%$ & $7 \%$ & $7 \%$ & Polymer \\
\hline PVP & $7 \%$ & $7 \%$ & $10.5 \%$ & $14 \%$ & Polymer \\
\hline PEG & $13 \%$ & $13 \%$ & $13 \%$ & $13 \%$ & Plasticizer \\
400 & & & & & \\
\hline Water & Ad & Ad 100 & Ad & Ad & Solvent \\
& 100 & & 100 & 100 & \\
\hline
\end{tabular}

Source: This formula is modified from Akuba Research (2019)

\section{E. Patch Making}

1) Put PVA into water that has been heated at a temperature above $100 \mathrm{oC}$ while stirring until it forms a gel mass

2) Enter PEG 400 into the gel mass, stirring until homogeneous

3) Dissolve PVP K30 with $96 \%$ ethanol, put it in the gel mass

4) Add celery leaf extract to each formula as much as $15 \%$, stirring until homogeneous

5) Add water to the gel mass up to $100 \mathrm{ml}$

6) Pour the gel mass into a mold that has been coated with aluminum foil and dry at room temperature until cool then covered with aluminum foil and let it dry.

7) After drying, cut the patch to a size of $2 \times 2 \mathrm{~cm} 2$. Then stick the patch on the Hypafix plaster with a size of $5 \times 3 \mathrm{~cm}$

\section{F. Patch Evaluation}

Evaluation that will be carried out, among others, $\mathrm{pH}$, weight uniformity, patch thickness, folding resistance, moisture content test, organoleptic (color, shape, and odor) after storage for 28 days, namely on days 0,7 , 14,21 , and 28.

1) $\mathrm{pH}$

This was done by inflating the patch in $1 \mathrm{ml}$ of aqua dest for 2 hours at room temperature, then the $\mathrm{pH}$ was recorded. Repeat up to three times and calculate the average

2) Weight Uniformity

The weight uniformity is done by randomly selecting about 10 of the number of patches and weighing them in digital balance. Calculate the average weight and standard deviation of individual weights. The determination is made for each formulation

3) Patch Thickness

Patch thickness is measured using a micrometer, with an amount of at least $0.01 \mathrm{~mm}$. Film thickness was measured at 5 different points and an average of 5 readings was taken. [13]

4) Folding Durability

The resistance of patch folding can be measured repeatedly by folding a small piece of film $(2 \times 2$ $\mathrm{cm})$ in the same spot until it breaks. The amount of time the film can be folded in the same place without breaking indicates the resistance of patch folding (10)

\section{5) Moisture Percentage}

The percentage of moisture contained in the patch can be calculated using an analytical weighing tool. The weighted patches were initially stored in a desiccator containing anhydrous calcium chloride or active silica at room temperature for 24 hours. After that, each patch was weighed repeatedly until they showed a constant weight. The calculation of the percentage of water content is done by comparing the difference between the initial and final weight divided by the final weight(10)

6) Color and Odor

Tests were carried out on changes in color and smell by involving 30 respondents who were randomly selected, then the respondents would evaluate the preparation by observing changes in color and smell during 28 days of storage

\section{RESULT}

\section{Evaluation result}

Table 2. Results of $\mathrm{pH}$ test for Repellent Patch Preparation of Methanol Extract of Celery Leaves (Apium graveolens .L) for 28 days of storage.

\begin{tabular}{lcccccc}
\hline \multicolumn{1}{c}{ Formula } & \multicolumn{5}{c}{$\mathrm{pH}$ Day- } & Desc \\
& 0 & 7 & 14 & 21 & 28 & \\
\hline Control & 6.73 & 6.83 & 6.85 & 6.88 & 6.95 & $\mathrm{M}$ \\
\hline Formula I & 5.58 & 5.68 & 5.64 & 5.68 & 5.71 & $\mathrm{M}$ \\
\hline Formula II & 5.23 & 5.25 & 5.24 & 5.29 & 5.32 & $\mathrm{M}$ \\
\hline Formula III & 4.52 & 4.58 & 4.59 & 4.61 & 4.63 & $\mathrm{M}$ \\
\hline
\end{tabular}

Eligible if $\mathrm{pH}$ is at $4.0-8.0$ (Aulton, 2002)

Table description: $\mathrm{M}=$ meets the requirements $\mathrm{NM}=$ does not meet the requirements 
Table 3. Results of Observation Weight Uniformity of Preparations Repellent Patch Celery Leaf Methanol Extract (Apium graveolens .L) During 28 Days of Storage
Folding Endurance who meet the requirements, namely> 300 times (Fitriyah, 2013)

Information

$\mathrm{M}=$ meets the requirements

$\mathrm{NM}=$ does not meet the requirements

Table 6. Results of Observation of Moisture Percentage of Preparations Repellent Patch Celery Leaf Methanol Extract (Apium graveolens .L) during 28 Days of Retention

\begin{tabular}{|c|c|c|c|c|c|c|c|c|c|c|c|}
\hline \multirow{3}{*}{$\begin{array}{l}\text { Repellen } \\
\text { t Patch }\end{array}$} & \multicolumn{10}{|c|}{ Days to- } & \multirow[t]{2}{*}{ info } \\
\hline & 0 & & 7 & & 14 & & 21 & & & 28 & \\
\hline & $\begin{array}{c}\text { Score } \\
(\mathrm{g})\end{array}$ & $\begin{array}{c}\begin{array}{l}\text { RSD } \\
(\%)\end{array} \\
\end{array}$ & $\begin{array}{c}\text { Score } \\
(\mathrm{g})\end{array}$ & $\begin{array}{l}\text { RSD } \\
(\%)\end{array}$ & $\begin{array}{c}\text { Score } \\
(\mathrm{g})\end{array}$ & $\begin{array}{l}\text { RSD } \\
(\%)\end{array}$ & $\begin{array}{c}\text { Score } \\
(\mathrm{g})\end{array}$ & $\begin{array}{l}\text { RSD } \\
(\%)\end{array}$ & $\begin{array}{c}\text { Score } \\
(\mathrm{g})\end{array}$ & $\begin{array}{c}\mathrm{RSD} \\
(\%)\end{array}$ & \\
\hline $\begin{array}{l}\text { Control } \\
\text { formula }\end{array}$ & 0.1443 & 0.32 & 0.1450 & 0.32 & 0.1456 & 0.36 & 0.1465 & 0.37 & 0.1480 & 0.29 & M \\
\hline $\begin{array}{l}\text { Formula } \\
\text { I }\end{array}$ & 0.1451 & 0.18 & 0.1461 & 0.22 & 0.1467 & 0.22 & 0.1472 & 0.22 & 0.1477 & 0.23 & M \\
\hline $\begin{array}{l}\text { Formula } \\
\text { II }\end{array}$ & 0.1478 & 0.22 & 0.1482 & 0.16 & 0.1487 & 0.22 & 0.1491 & 0.19 & 0.1497 & 0.24 & M \\
\hline Formula I] & 0.1530 & 0.18 & 0.1535 & 0.17 & 0.1541 & 0.15 & 0.1547 & 0.19 & 0.1553 & 0.33 & M \\
\hline
\end{tabular}

Uniformity of weights that meet the requirements with a relative standard deviation of $<6 \%$ (Windriyati, 2016) Information: $M=$ meets the requirements $\mathrm{NM}=$ does not meet the requirements RSD: Relative Standard Deviation

Table 4. Observation Results of Thickness of Preparations Repellent Patch Celery Leaf Methanol Extract (Apium graveolens .L) During 28 Days of Storage

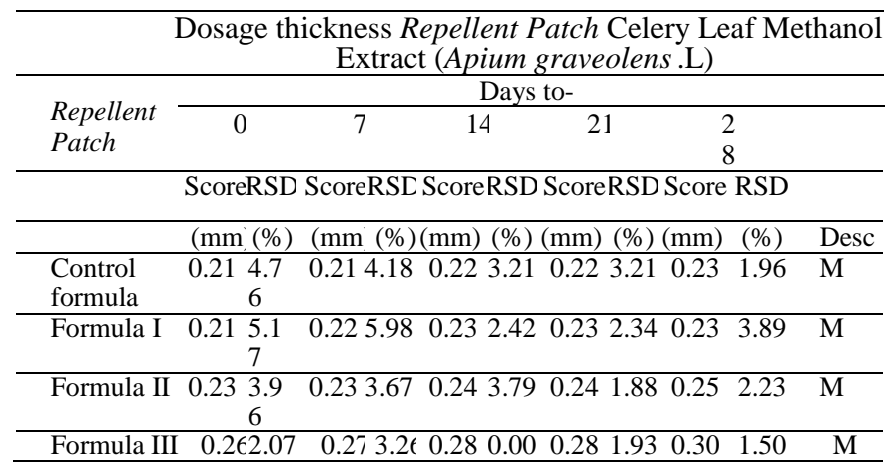

The thickness that meets the requirements with a relative standard deviation of $<6 \%$ (Windriyati, 2016) Information

$\mathrm{M}=$ meets the requirements

$\mathrm{NM}=$ does not meet the requirements RSD:

Standard Deviation Relative

Table 5. Results of Observation of the Folding Endurance of Preparations Repellent Patch Celery Leaf Methanol Extract (Apium graveolens .L) During 28 Days of Storage

\begin{tabular}{|c|c|c|c|c|c|c|}
\hline \multirow{3}{*}{ Repellent Patch } & \multicolumn{5}{|c|}{$\begin{array}{c}\text { Folding Endurance Preparations } \\
\text { Repellent Patch Celery Leaf Methanol } \\
\text { Extract (Apium graveolens .L) }\end{array}$} & \multirow{3}{*}{$\begin{array}{c}\text { Informa } \\
\text { tion }\end{array}$} \\
\hline & \multicolumn{5}{|c|}{ Days to - } & \\
\hline & 0 & 7 & 14 & 21 & 28 & \\
\hline Control formula & $>300$ & $>300$ & $>300$ & $>300$ & $>300$ & M \\
\hline Formula I & $>300$ & $>300$ & $>300$ & $>300$ & $>300$ & M \\
\hline Formula II & $>300$ & $>300$ & $>300$ & $>300$ & $>300$ & $M$ \\
\hline Formula III & $>300$ & $>300$ & $>300$ & $>300$ & $>300$ & $\mathrm{M}$ \\
\hline
\end{tabular}

\begin{tabular}{|c|c|c|c|c|c|c|}
\hline - & \multicolumn{5}{|c|}{$\begin{array}{c}\text { Moisture percentage Repellent Patch } \\
\text { Celery Leaf Methanol Extract } \\
\text { (Apium graveolens .L) }\end{array}$} & \multirow{3}{*}{$\begin{array}{l}\text { Informati } \\
\text { on }\end{array}$} \\
\hline 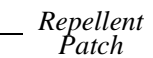 & \multicolumn{5}{|c|}{ Days to - } & \\
\hline- & 0 & 7 & 14 & 21 & 28 & \\
\hline $\begin{array}{l}\text { Control } \\
\text { formula }\end{array}$ & $6.44 \%$ & $6.45 \%$ & $6.65 \%$ & $6.82 \%$ & $6.97 \%$ & M \\
\hline Formula I & $5.79 \%$ & $6.14 \%$ & $6.17 \%$ & $6.31 \%$ & $6.46 \%$ & M \\
\hline Formula II & $6.67 \%$ & $6.82 \%$ & $6.93 \%$ & $6.95 \%$ & $6.97 \%$ & M \\
\hline Formula III & $7.02 \%$ & $7.66 \%$ & $7.72 \%$ & $7.76 \%$ & $7.94 \%$ & M \\
\hline
\end{tabular}

The percentage of moisture that meets thE requirements is $1-10 \%$ (Adikusumo, 2015)

Information: $\mathrm{M}=$ meets the requirements $\mathrm{NM}=$ does not meet the requirements

Table 7. Result of Color Observation Repellent Patch Celery Leaf Methanol Extract (Apium graveolens .L) during 28 Days of Retention

\begin{tabular}{lcccc}
\hline & \multicolumn{3}{c}{$\begin{array}{c}\text { Result of Color Observation Repellent } \\
\text { Patch Celery Leaf Methanol Extract } \\
\text { Repellent Patch }\end{array}$} & \multicolumn{4}{c}{$\begin{array}{c}\text { graveolens } \\
\text {.L) }\end{array}$} \\
\cline { 2 - 5 } & $\mathrm{C}$ & $\%$ & $\mathrm{NC}$ & $\%$ \\
\hline Control formula & 0 & $0 \%$ & 30 & $100 \%$ \\
Formula I & 0 & $0 \%$ & 30 & $100 \%$ \\
Formula II & 0 & $0 \%$ & 30 & $100 \%$ \\
Formula III & 0 & $0 \%$ & 30 & $100 \%$ \\
\hline
\end{tabular}

Description: $\mathrm{C}$ : Change $\mathrm{NC}$ : Do not change

Table 8. Results of odor observations of preparations Repellent Patch Celery Leaf Methanol Extract (Apium graveolens .L) during 28 Days of Retention

\begin{tabular}{lcccc}
\hline & \multicolumn{3}{c}{$\begin{array}{c}\text { Results of odor observations of } \\
\text { preparations Repellent Patch Celery Leaf } \\
\text { Repellent Patch }\end{array}$} & \multicolumn{4}{c}{$\begin{array}{c}\text { Methanol Extract (Apium } \\
\text { graveolens .L) }\end{array}$} \\
\cline { 2 - 5 } & $\mathrm{C}$ & $\%$ & $\mathrm{NC}$ & $\%$ \\
\hline Control formula & 0 & $0 \%$ & 30 & $100 \%$ \\
Formula I & 0 & $0 \%$ & 30 & $100 \%$ \\
Formula II & 0 & $0 \%$ & 30 & $100 \%$ \\
Formula III & 0 & $0 \%$ & 30 & $100 \%$ \\
\hline
\end{tabular}

Description: $\mathrm{C}$ : Change NC : Do not change 


\section{DISCUSSION}

\section{A. $p H$}

The $\mathrm{pH}$ of the repellent patch control formula, I, II, III for 28 days of the storage fulfilled the requirements although there was an increase but was still in the $\mathrm{pH}$ range 4-8. This is due to the addition of the concentration of PVP which functions as a polymer that has an acidic $\mathrm{Ph}$.

\section{B. Weight Uniformity}

The repellent patch weight for each formula has increased. Formula III has the greatest weight due to the combination of polymer concentration and higher PVP content. This shows that PVP can increase the weight of the patch (Rowe, Sheskey, and Quinn, 2009). Overall, the repellent patch weight increased during 28 days of storage. However, the repellent patch weight on the control formula, formula I, formula II, formula III is declared uniform so that it meets the requirements.

\section{Patch Thickness}

The thickness of the repellent patch for each formula is different and has increased. This is in line with the weight of the repellent patch, the greater the weight of the patch, the thicker the patch. The thickness of the repellent patch increased during 28 days of storage, this was due to the hygroscopic nature of the PVP as well as the overall polymer combination. However, the thickness of the repellent patch throughout the formula is uniform so that it meets the requirements.

\section{Folding Durability}

The entire repellent patch formula meets the requirements for multiplying durability because $>300$ times the fold does not suffer damage. This is due to the addition of propylene glycol as a plasticizer which increases the flexibility of the repellent patch.

\section{E. Moisture Percentage}

The repellent patch moisture percentage of each formula has increased. This is due to differences in the concentration of PVP. The water-absorbing property of PVP in the air can increase the percentage of moisture in the patch. So that the higher the PVP concentration, the higher the percentage of moisture in the repellent patch. The formula I have the lowest percentage of moisture with the lowest PVP concentration. The percentage of repellent patch moisture increased during 28 days of storage, this was due to the hygroscopic nature of PVP. However, the percentage of repellent patch moisture throughout the formula meets the requirements.

\section{F. Color and Odor}

Color and odor repellent patch containing celery leaf extract celery (Apium graveolens L) During storage, 30 respondents stated that the repellent patch did not experience discoloration and odor.

\section{CONCLUSION}

The methanol extract of celery leaves (Apium graveolens .L) can be formulated into a stable and compliant repellent patch with optimal PVP variations at a concentration of $10.5 \%$. including $\mathrm{pH}$, weight uniformity, thickness, folding resistance, percentage of moisture for 28 days of storage.

\section{ACKNOWLEDGMENT}

The author is grateful to the Health of Polytechnic of Palembang for assisting in funding under the Icohost 2020 research scheme.

\section{REFERENCES}

[1] Verma, NK Vishwakarma A. An Overview on Transdermal Patches. Pharm Rev Res. 2017;7 (1):17-23.

[2] Ministry of Health. Data and Information. Jakarta. attachment 6. Jakarta; 2018.

[3] Chattopadhyay $\mathrm{P}$ et al. Ultra low concentration deltamethrin loaded patch development and evaluation of its repellency against dengue vector Aedes (S) albopictus: 1-10. 2013. 1-10 p.

[4] Journal W, Pharmacypharmaceutical OF, Lohitasu D, Lohitasu D. Applicability of Natural Polymers in Transdermal Patches : Overview. 2016;(December).

[5] Fatmawaty A et al. Formulasi Patch Ekstrak Etanol Daun Murbei (Morus Alba L. dengan Variasi Konsentrasi Polimer Polivinil Pirolidon dan Etil Selulosa. J Pharm Med Sci. 2017;2(1):17-20.

[6] Pakaya, MS Thomas, NA, Idris P. [Effectiveness Test of Clove Leaf Extract (Syzygium Aromaticum) Patch Preparation as Mosquito Repellent. 2019;1 (1):28-36.

[7] Department of Health and Human Services. Toxicological Profile for Chlorodibenzofurans. 2002. 144 p.

[8] Akuba, J., Thomas, Nurain., Palay RDJ. Effects of Duan Celery Methanol Extract (Apium graveolens L) as an insecticide against mosquitoes. J Syifa Sci Clin Res. 2019;1 (1):1.

[9] Sh Abou-Elnaga Z. Insecticidal bioactivity of eco- friendly plant origin chemicals against Culex pipiens and Aedes aegypti (Diptera: Culicidae). J Entomol Zool Stud. 2014;2 (6):340-7.

[10] Tuetun B et al. Repellent properties of celery, Apium graveolens L., compared with commercial repellents, against mosquitoes under laboratory and field conditions. ropical Med Int Heal. 2005;10 (11):1190-8. 